\title{
MERETAS JALAN MENINGKATAN PENDAPATAN ASLI DAERAH (PAD) MELALUI DESA WISATA PANGLIPURAN BALI ${ }^{1}$
}

\section{INITIATING THE PATHWAY TO INCRESE THE REGION'S INCOME BY DEVELOPING TOURISM VILLAGE OF PANGLIPURAN BALI}

\author{
M. Bashori Imron \\ Peneliti P2KK-LIPI \\ Kompleks Widya Graha Lantai IX C.17 Jalan Gatot Subroto No 10 Jakarta Selatan \\ Email: bhosyenfia@yahoo.co.id \\ Dikirim: 22 Juli 2015 Direvisi: 15 Agustus 2015 Disetujui: 20 Oktober 2015
}

\begin{abstract}
Abstraksi
Kepala Daerah Kabupaten/Kota perlu mengembangkan imajinasi dan inspirasi agar mampu menunjukkan tujuan pembangunan daerah dan mampu mendatangkan kesejahteraan masyarakat. Salah satunya adalah menginisiasi desa yang memiliki potensi untuk dikembangkan menjadi desa wisata. Tujuan penelitian adalah untuk pengembangkan desa wisata sebagai bentuk alternatif peningkatan sumber Pendapatan Asli Daerah (PAD). Metode yang digunakan adalah dengan terlibat langsung di desa wisata Penglipuran, serta wawancara dengan stakeholder bidang pariwisata. Hasil penelitian menunjukkan bahwa desa wisata Penglipuran Bali memiliki tujuh potensi desa sebagai daya tarik pariwisata, yaitu Rumah Adat yang unik, Penatan tata ruang yang seragam, Hutan Bambu, Makam Pahlawan, Keindahan Pura Penataran, Keindahan Alam Pedesaan, dan Karang Memadu. Campur tangan Pemerintah Daerah dapat mendorong peningkatan Pendapatan Asli Daerah (PAD) sekaligus meningkatkan kesejahteraan masyarakat.
\end{abstract}

Kata Kunci : Desa Wisata, Potensi, dan Pendapatan Asli Daerah

\section{Abstract}

The head of regencies and cities needs to develop their imagination and inspiration in order to present the goal of region development and deliver the positive economic growth for the public. Initiating the tourism village programm for the potential area may serve as a creative alternative. The aim of this research is to develop the idea of tourism village to improve the income of the region. In depth participation in the community and intensive interview with the tourism stakeholders have been chosen as the method of this study. The result of the research shows that the tourism village of Penglipuran has seven potentiala as the main attractions as represented by the traditional architecture, artistic spatial arragement, the bamboo forest, heroes cemetry, the beauty of pura Panataran, remarkeble village landscape, and Karang Memadu. The participation of local government may contribute the positive impact for the economic grouth and improve the income of local community.

Keywords : Tourism village, Potential, and income of the region

\footnotetext{
${ }^{1}$ Sebagian isi makalah ini dikembangkan dari tulisan penulis pada Laporan Hasil Penelitian Pusat Penelitian Kemasyarakatan dan Kebudayaan LIPI Tahun 2014 tentang Model Community Empowerment Dalam Industri Pariwisata
} 


\section{PENDAHULUAN}

Semenjak Perserikatan Bangsa Bangsa (PBB) menetapkan Millenium Development Goal (MDGs) akhir tahun 2000 mendorong semua negara untuk memfokuskan perhatiannya pada agenda pengentasan kemiskinan dan langkahlangkah penerapannya. Hal ini menjadi hal yang lumrah karena deklarasi MDGs menempatkan masalah kemiskinan dan kelaparan pada proritas pertama dari delapan unggulan prioritasnya. Bahkan secara ambisius, PBB mentargetkan penghapusan setengah dari penduduk miskin di dunia harus dapat dientaskan pada tahun 2015. Di Indonesia dengan ditetapkannya Undang Undang Kepariwisataan Nomor 10 Tahun 2009, sebagai penyempurnaan undang undang kepariwisataan sebelumnya yang ditetapkan tahun 1990, menegaskan pentingnya peran pariwisata dalam membantu mengurangi membludaknya pengangguran, dan juga meretas jalan mengentaskan kemiskinan, terutama masyarakat marjinal. Kondisi ini, menunjukkan bahwa Indonesia juga menyiapkan langkah langkah untuk melaksanakan prioritas dari kesepakatan MDGs dengan merujuk pada tingkat pengangguran dan tingkat kemiskinan. Dan lahirlah berbagai kebijakan untuk mencapai kondisi tersebut, salah satunya melalui pembangunan desa yang memiliki potensi untuk dikembangkan menjadi Desa Wisata.

Beberapa hasil penelitian yang dikutip oleh Putra dan Pitana (2010:15-16) dalam buku Pariwisata Pro Rakyat: Meretas Jalan Mengentaskan Kemiskinan di Indonesia mengemukakan sebagai berikut:

"Kajian rintisan dengan inisiatif dari sarjana Indonesia mengenai peranan pariwisata untuk penanggulangan kemiskinan di Indonesia ditandai dengan terbitnya buku dan hasil kajian dari Pusat Studi Pariwisata Universitas Gajah Mada. Pertama buku Penanggulangan Kemiskinan Melalui Pariwisata, 2005 hasil suntingan Janianton Damanik, Hendrie Aji Kusworo, dan DesthaT Raharjana. Kedua, berupa laporan Heritage Tourism in East Nasa Tenggara: Contributing to The Millenium Development Goal, 2009. Kajian ini Pusat Studi Pariwisata Universitas Gajah Mada didukung oleh Unesco. Menyadari tingginya angka kemiskinan di NTT dan sadar bahwa kemiskinan bisa ditanggulangi dengan penciptaan lapangan kerja. Untuk lapangan kerja ini, mereka melihat pariwisata memainkan peranan penting mengingat NTT memiliki banyak potensi alam dan warisan budaya yang bisa dikembangkan sebagai daya tarik wisata. Dalam kajian ini dibuat beberapa skenario pengembangan pariwisata untuk menanggulangi kemiskinan. Menariknya kajian ini dibuat dengan tujuan untuk memberikan konstribusi pada program pengentasan kemiskinan MDGs. Genesis buku Penanggulangan Kemiskinan melalui Pariwisata adalah makalah yang dibahas dalam workshop dengan tema seputar pariwisata dan penanggulangan kemiskinan bekerjasama dengan Menko Kesra, Damanik Kusworo dan Raharjana, 2005 ".

Kita semua warga bangsa Indonesia menyadari bahwa pariwisata memiliki keunggulan positif yang dapat dimanfaatkan oleh masyarakat. Hal ini disebabkan karena pariwisata dapat diikuti oleh berbagai tingkat keahlian atau keterampilan, berbagai tingkatan sosial, berbagai sifat lokasi desa dan kota, serta tidak diskriminatif terhadap jender. Kompetensi masyarakat dengan keterampilan rendah (pijid di pantai, buat tattoo, dst) maupun keterampilan tingkat tinggi (menejer, dst); pemilik modal (pengusaha) maupun masyarakat yang tidak memiliki modal (toko/penjaja souvenir,dst), semuanya dapat dilibatkan dalam pariwisata. Demikian halnya dengan masyarakat perdesaan (jauh dari sarana prasarana memadai dengan wisata desanya) maupun masyarakat perkotaan (wisata kuliner, dst); maupun masyarakat yang berjenis kelamin laki-laki maupun perempuan, dengan mudahnya dapat terlibat dalam uhasa jasa pariwisata. Namun perlu diingat bahwa keterlibatan semua klasifikasi masyarakat tersebut, juga dapat melahirkan sisi negatif.

Hasil penelusuran pustaka yang dilakukan oleh Tahajuddin dkk (2013, 2014) diklasifikasi beberapa hasil penelitian yang terkait dengan positif dan negatifnya usaha pariwisata dijelaskan pada Tabel 1.

Terlepas dari sifat pariwisata yang positif maupun negatif, Mitchell dan Ashley (2010) menyatakan bahwa terdapat tiga jalur manfaat industri pariwisata yang dapat mengalir ke tangan masyarakat marjinal, yaitu: Direct Effects of tourism On the Poor, Secondary effects, dan Dynamic effects. Peran pariwisata di masyarakat yang pertama adalah Direct Effects of tourism On the Poor yaitu efek langsung pariwisata pada masyarakat marjinal. Contoh dari peran pariwisata yang pertama ini meliputi pendapatan sektor pariwisata, seperti gaji pegawai hotel dan restoran atau sopir taksi. Efek langsung ini tidak selamanya berbentuk uang, namun dapat juga bersifat nonfinalsial berupa peningkatan infra struktur akses ke pantai untuk penduduk lokal. Peran pariwisata yang kedua adalah Secondary effects. Peran pariwisata ini dapat berupa pendapatan yang tidak langsung maupun dampak tidak langsung pada kehidupan dari sektor non-wisata yang tumbuh akibat aktivitas pariwisata. Bentuk aktivitas dari peran yang kedua ini misalnya pengrajin, pekerja konstruksi (bangunan) petani, dst. Termasuk didalamnya induced effects atau efek ikutan dari pekerja pariwisata yang membelanjakan uangnya dalam domain ekonomi lokal. Peran pariwisata yang ketiga adalah Dynamic effects atau dampak 
Tabel 1. Dampak Sosial-Budaya Pariwisata Menurut Beberapa Penulis

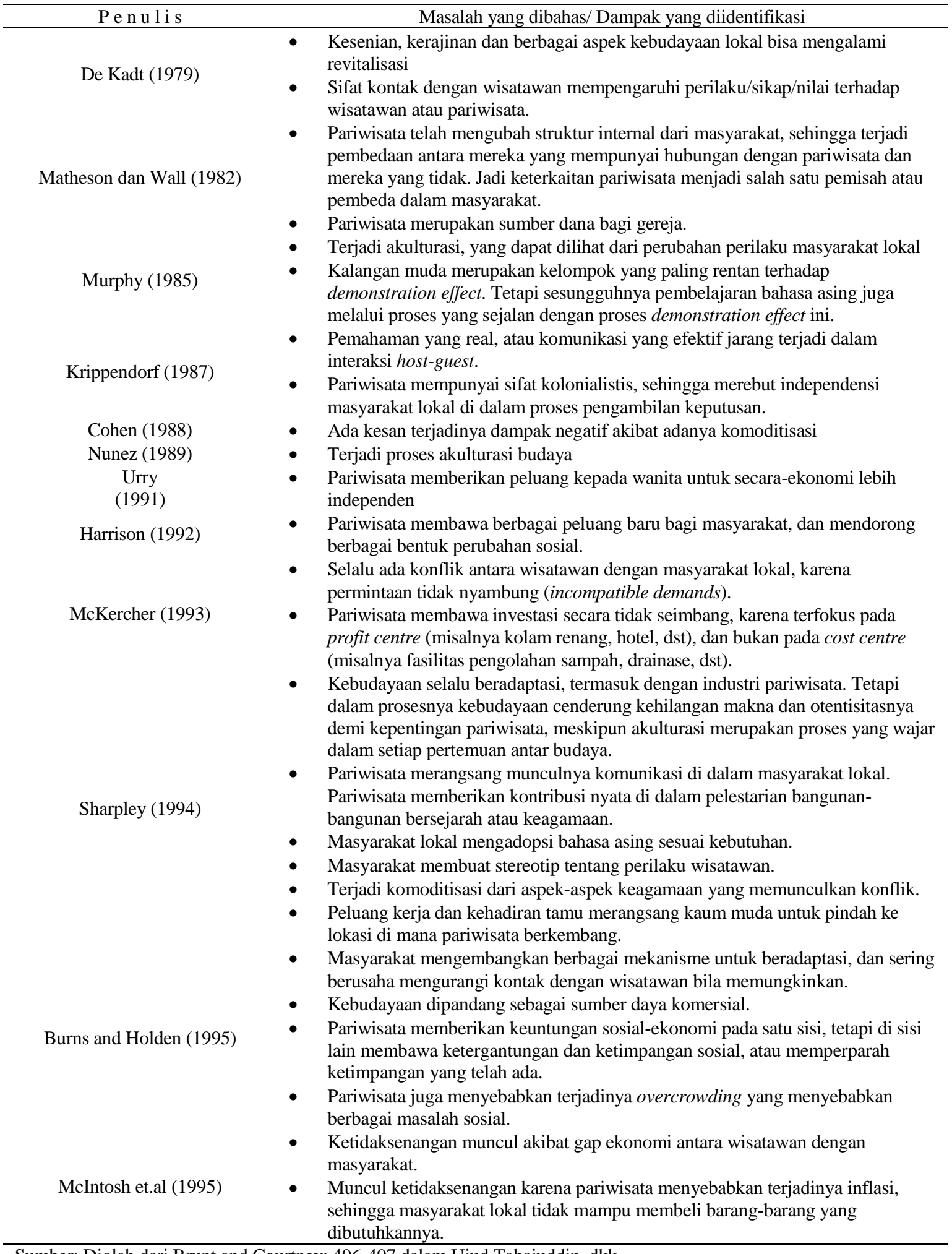

Sumber: Diolah dari Brunt and Courtney: 496-497 dalam Ujud Tahajuddin, dkk.

dinamik. Dampak ini cukup luas mencakup perubahan jangka panjang dalam perekonomian; baik ekonomi makro atau ekonomi lokal di daerah tujuan wisata.. Beberapa efek lingkungan seperti erosi dari asset alam pembangunan pariwisata dapat dianggap sebagai dampak dinamis. Semua efek di atas dapat dikembangkan melalui pembangunan pariwisata dengan menelusuri potensi desa yang dapat dijadikan sebagai tujuan pariwisata; yang dikenal dengan Desa Wisata. Desa wisata itu sendiri, sudah sejak lama didengungkan sebagai alternatif pengembangan objek pariwisata 
konvensional. Banyak pendapat dari para ahli tentang perlunya pengembangan desa wisata sebagai salah satu jawaban dari sisi-sisi negatif pariwisata itu sendiri. Prinsip pengembangan pariwisata adalah azas manfaat bagi masyarakat setempat, dimana prioritas untuk menikmati hasilhasil pembangunan aspek pariwisata semestinya dinikmati oleh masyarakat setempat. Desa wisata (Pitana, 1999:105) merupakan bentuk lain dari rural tourism, farm tourism, atau village tourism, membawa visi dan misi yang jelas, sebagai remedi terhadap berbagai kelemahan yang dirasakan selama ini. Namun demikian, pengembangan desa wisata merupakan alternatif yang sangat sensitif, karena kesalahan dalam perencanaan dan pengelolaan dapat berakibat buruk terhadap eksistensi desa adat.Desa wisata (Putra, 2010:70) didefinisikan sebagai pengembangan desa menjadi destinasi wisata dengan sistem pengelolaan yang bersifat, dari, oleh, dan untuk masyarakat. Dalam konsep desa wisata, peran aktif pembangunan dan pengelolaan desa wisata berada di tangan masyarakat desa. Masyarakat desa, entah lewat lembaga koperasi atau yayasan, secara pro aktif mengelola daya tarik wisata di daerahnya dengan mengundang wisatawan untuk datang sekaligus untuk bermalam karena desa wisata juga menawarkan pelayanan akomodasi. Pengertian desa wisata lebih mudah dipahami jika dibandingkan dengan wisata desa. Yang dimaksudkan dengan wisata desa adalah kegiatan berwisata ke suatu desa atau dari satu desa ke desa lainnya yang memiliki daya tarik, diantar oleh pemandu wisata; sedangkan masyarakat dan desanya hanya menjadi objek untuk dikunjungi. Dalam desa wisata, peran masyarakat lebih menonjol, mereka menjadi subjek pengelola kunjungan wisatawan ke desa mereka. Dalam hal ini, masyarakat desa tidak menjadi penonton tetapi menjadi pemain yang aktif mengelola daya tarik wisata di desanya sehingga akhirnya bisa mendapatkan keuntungan ekonomi dari aktifitas tersebut.

Oleh karena itu. para kepala daerah harus mempunyai imajinasi dan inspirasi agar mampu menunjukkan tujuan pembangunan daerah dan mampu mendatangkan kesejahteraan bagi masyarakat yang dipimpinnya. Imajinasi dan inspirasi yang dimaksud, salah satunya adalah menginisiasi desa yang memiliki potensi untuk dikembangkan menjadi desa wisata. Entah keindahan alamnya, entah keseniannya, entah spesifik desa lainnya. Dengan demikian kepala daerah yang memiliki imajinasi berarti dapat memberikan yang terbaik bagi rakyatnya. Sebagaimana diketahui bahwa pariwisata Bali telah memiliki kemampuan mendongkrak perekonomian masyarakat serta dipuja oleh dunia sebagai surga karena alamnya yang indah. Membicarakan Bali dari berbagai sisi, maka pariwisata akan dijadikan sebagai elemen dasar. Demikian halnya dengan membicarakan pariwisata di segala tingkatan lokal dan nasional, Bali selalu dijadikan rujukan untuk dicontoh. Namun, pariwisata Bali juga dijadikan sebagai kambing hitam munculnya kondisi negatif dari berbagai dinamika perkembangan masyarakat. Sisi negatif pariwisata yang dimaksud dinyatakan oleh berbagai sumber literatur antara lain disebutkan bahwa: pariwisata telah mengubah struktur internal dari masyarakat, sehingga terjadi pembedaan antara mereka yang mempunyai hubungan dengan pariwisata dan mereka yang tidak. Jadi keterkaitan pariwisata menjadi salah satu pemisah atau pembeda dalam masyarakat (Matheson dan Wall, 1982). Demikian halnya dengan kesenian, kerajinan dan berbagai aspek kebudayaan lokal bisa mengalami revitalisasi (De Kadt, 1979), atau Pariwisata juga menyebabkan terjadinya overcrowding yang menyebabkan berbagai masalah sosial (Burns and Holden, 1995). ${ }^{2}$

Oleh karena itu, kelahiran desa wisata dianggap sebagai salah satu jalan keluar dan percontohan berkembangnya pariwisata, tanpa memunculnya sisi negatif dalam kehidupan masyarakat Bali dengan kebudayaannya. Akibatnya, berbagai kebijakan pemerintah daerah maupun tokoh masyarakat di Bali memiliki keinginan untuk mengembangkan pariwisata budaya. Salah satu yang dikembangkan saat ini adalah Desa adat Penglipuran Kabupaten Bangli sebagai Desa Wisata dan destinasi pariwisata Bali. Tahun 1990 para pemuka masyarakat desa adat penglipuran bekerjasama dengan Universitas Udayana Denpasar, berinisiatif merancang Desa Penglipuran menjadi desa wisata. Sejak itulah masyarakat Desa Penglipuran menata berbagai fasilitas desa yang dapat dijadikan unggulan sebagai sarana daya tarik pariwisata. Sebaliknya pemerintah daerah melakukan kajian dan kebijaksanaan yang mendukung terciptanya desa adat menjadi desa wisata. Desa wisata Penglipuran ini menjadi jawaban atas keluhan berbagai bendesa adat yang mengeluhkan keadaan di desanya dan sudah bukan menjadi rahasia, salah satu di antaranya menyatakan bahwa (Pitana, 1999: 107):

“.....wisatawan menginap di hotel berbintang (yang dimiliki oleh orang luar) lalu diatur oleh biro perjalanan mengunjungi pedalaman Bali, lengkap dengan bekal berbagai kebutuhan seperti minuman kaleng dan makanan kecil terbungkus plastik. Di pedesaan mereka menikmati indahnya pemandangan alam, sawah yang berteras, dan kebudayaan Bali yang eksotik, atau berbagai upacara yang dilakukan oleh desa adat dan subak.

\footnotetext{
${ }^{2}$ Selanjutnya dapat dilihat pada hasil penelitian Pusat Penelitian Kemasyarakatan dan Kedudayaan (P2KKLIPI) Tahun 2013 tentang Community Empowerment dalam Industri Pariwisata: Praktik Pemberdayaan Komunitas Lokal oleh Industri Kreatif Pendukung Pariwisata.
} 
Setelah puas menyaksikan dan membuat foto, lalu wisatawan digiring makan siang di restoran mewah (yang juga dimiliki oleh orang luar) lalu pulangnya membeli cinderamata di art shop, lalu apa yang didapatkan oleh desa adat, yang menjadi objek dan penyedia atraksi, tidak ada, kecuali plastik bekas pembungkus makanan dan botol minuman"

Pariwisata Bali bertumpu pada kebudayaan Bali, maka pelestarian kebudayaan Bali merupakan sesuatu yang tidak bisa ditawar-tawar, agar pariwisata dapat berkembang secara berkelanjutan (sustainable). Demikian halnya dengan desa adat dan subak merupakan pilar-pilar kebudayaan Bali, maka pelestarian kebudayaan Bali akan dapat dipertahankan dan hanya jika eksistensi desa adat dan subak dapat dipertahankan. Oleh karena itu, perlu adanya usaha untuk memberikan kesempatan agar desa adat semakin kuat eksistensinya, dengan memberikan kesempatan berpartisipasi dalam pembangunan pariwisata. Dengan perkataan lain, harus ada usaha agar pariwisata dapat memberikan manfaat langsung kepada desa adat.

\section{METODE}

Penelitian ini menggunakan metode survey dengan pendekatan kualitatif dan terlibat langsung di lapangan. Data primer diperoleh dengan melakukan wawancara terstuktur dengan nara sumber dari pemerintah daerah, forum penelitian pariwisata bali, pengelola desa wisata, serta dari Sekolah Tinggi Pariwisata Bali. Hasil wawancara direkam dan di transkip sesuai dengan kebutuhannya. Data sekunder diperoleh dari penelusuran hasil penelitian sejenis yang telah dilakukan oleh peneliti sebelumnya, serta bukubuku literatur terkait pariwisata yang sudah diterbitkan.

\section{HASIL DAN PEMBAHASAN}

\section{Tujuh Keunggulan Desa Wisata Penglipuran}

Desa Wisata Panglipuran ini terletak di Kelurahan Kubu, Kecamatan Bangli, Kabupaten Bangli. Hanya berjarak 45 kilo meter dari Kota Denpasar dan satu jalur menuju kawasan wisata Kintamani. Luas desa sekitar 112 hektar dengan ketinggian 700 meter di atas permukaan laut, sehingga memiliki udara yang sejuk. Secara spesifik desa wisata ini memiliki tidak kurang tujuh keunggulan yang merupakan daya tarik sebagai tujuan wisata, dan sebagaian dapat dikatakan sebagai keunggulan budaya yang dimiliki desa ini. I. Nengah Monang, ketua pengelola desa wisata mengemukakan bahwa terdapat paling tidak tujuh keunggulan Desa Adat Panglipuran yang merupakan daya tarik sebagai desa wisata $^{3}$. Ketujuh potensi desa yang dimaksud adalah:

1. Rumah Adat yang unik,

2. Penatan tata ruang yang seragam,

3. Hutan Bambu,

4. Makam Pahlawan,

5. Keindahan Pura Penataran,

6. Keindahan Alam Pedesaan, dan

7. Karang Memadu.

Keunggulan pertama adalah Rumah Adat yang Unik dan keunggulan kedua adalah Penataan Tata Ruang yang Seragam. Lokasi desa wisata Penglipuran memang didukung oleh kontur tanah yang menarik, dimana kondisi bangunan dari awal masuk desa sampai pada bangunan Pura, terus menanjak. Kultur tanah desa wisata ini, dilihat dari bawah seolah-olah kita berjalan dari dasar ke atas sampai ke kepala yang terdapat bangunan Pura Penataran dan Pura Puseh. Di sepanjang jalan koridor desa hanya digunakan untuk pejalan kaki. Sisi kanan kiri jalan koridor menuju ke atas terdapat rumah-rumah dengan bentuk bangunan dan bahan yang dipakai sama antara yang satu dengan yang lain. Semua rumah dilengkapi dengan atribut struktur desa seperti : tembok penyengker, angkul-angkul (candi bentar khas), dan telajakan yang seragam, serta atap dari bambu yang dibelah untuk seluruh bangunan desa.

Kondisi seperti ini, diibaratkan sebagai tata ruang Tri Mondal yaitu seperti tubuh manusia yang memiliki kepala, badan dan kaki. Kepala (bagian atas) disebut sebagai Pertiangan yang berarti memiliki hubungan dengan Tuhan. Badan (bagian tengah) disebut dengan Pawongan diartikan sebagai hubungan antar manusia, sedangkan kaki (bagian bawah) disebut palemahan yang berarti hubungan dengan lingkungan. Hubungan dengan lingkungan, dapat dipersepsikan bahwa manusia tidak boleh semena-mena mengekploisasi lingkungan, tanpa memikirkan pelestariannya. Manusia hidup tidak dapat menyendiri, tetapi sebagai mahluk sosial tetap harus melakukan hubungan dengan manusia lainnya. Demikian halnya dengan hubungan dengan Tuhan, manusia wajib menjaga keseimbangan antara kepentingan di dunia dan kepentingan di alam setelah meninggal.

Keunggulan ketiga adalah hutan bambu. Hutan bambu ini mengelilingi seluruh desa wisata yang di sela-sela jalan setapak dipergunakan untuk wisata sepeda yang disebut dengan Penglipuran Village Tracking Tour dan aktivitas Penglipuran Rural Cycling Tour. Disamping itu, pohon bambu ini dapat meneduhkan jalan yang digunakan oleh wisatawan yang mengelilingi desa, baik dengan jalan kaki mapun menggunakan sepeda. Ditambah dengan udara yang sejuk, menjadikan desa ini

\footnotetext{
${ }^{3}$ Hasil wawancara dengan I Nengah Monang, Ketua Paguyupan Pengelola Desa Wisata Penglipuran pada tanggal 13 Agustus 2014 di Pengliran Bali
} 
sangat nyaman untuk melakukan olah raga. Bambu ini dipergunakan untuk atap dan dinding rumah sebagai suatu keharusan. Keunggulan keempat adalah Taman Makam Kapten Mudita. Pemakaman ini ditata dengan baik, sehingga dapat digunakan sebagai daya tarik wisata sejarah.

Keunggulan kelima adalah Keindahan Pura Penataran. Sebagaimana dijelaskan di atas bahwa lokasi pura penataran ini ada di kontur tanah bagian atas yang disebut Pertiangan yang berarti memiliki hubungan dengan Tuhan. Tim Peneliti mempersepsikan bahwa kehidupan manusia berakhirnya adalah kembali kepangkuan Tuhan Yang maha Esa. Keunggulan keenam adalah Keindahan Alam Pedesaan yang Alami. Memasuki Desa wisata Penglipuran ini seperti memasuki desa alami yang belum terjamah oleh tangan manusia. Masyarakat yang memiliki tingkat sosial tinggi dan rendah, bersama-sama mematuhi ketentuan adat. Jalan koridor yang disebutkan sebelumnya tidak memperlihatkan tingkatan sosial yang berbeda, semua bentuk bangunan dan bahan bangunannya sama. Padahal dibalik itu, bangunan rumahnya sangat berbeda. Baik luas bangunan maupun bentuk bangunannya, termasuk garasi mobil yang terletak di belakang rumah.

Sarana penginapan berupa guest house dan homestay berbagai tipe, sudah tersedia, sehingga pengunjung dapat langsung berinteraksi dengan pemilik home stay, sekaligus berinteraksi dengan kebudayaannya. Home stay tersebar di beberapa rumah warga memiliki berbagai tipe yaitu tipe $A$, tipe $\mathrm{B}$, tipe $\mathrm{C}$, dan tipe $\mathrm{C}$; seperti layaknya ukuran hotel berbintang. Jadi latar belakang pengembangan Desa wisata Penglipuran ini ${ }^{4}$ adalah kombinasi antara potensi daya alam dan budaya yang ada, serta kesadaran masyarakat untuk memanfaatkan potensi itu untuk pelestarian lingkungan, budaya, dan juga mendapatkan manfaat ekonomi.

Keunggulan ketujuh adalah Karang Memadu. Karang memadu ini hanya merupakan hamparan lahan kosong. Tersedianya lahan kosong ini dimaksudkan sebagai lahan yang hanya diperuntukkan bagi orang yang melakukan poligami atau disediakan bagi penduduk desa yang beristri lebih dari satu. Filosofi disediakannya Karang Memadu ini, perlu dikaji lebih lanjut, sebagai bagian dari budaya masyarakat setempat.

\footnotetext{
4 Terdapat beberapa desa wisata di Bali selain desa wisata Penglipuran ini, yaitu Desa Sebatu di Kabupaten Gianyar memiliki objek wisata Pura Indah dan Agung serta terkenal sebagai desa kerajinan ukir-ukiran kayu. Juga desa wisata Jatiluwih Kabupaten Tabanan yaitu desa yang memiliki 636 hektar areal persawahan dengan terasering yang indah. Bahkan tahun 2008 Desa Jatiluwih akan diusulkan menjadi salah satu natural heritage atau warisan alam dunia Unesco, tetapi gagal. Uraian tentang desa wisata tersebut diuarikan secara lengkap oleh I Nyoman Darma Putra dan I Gde Pitana .
}

Bangunan rumah disiapkan oleh desa adat, namun penghuni karang memadu tidak diperkenankan hidup berdampingan dengan penduduk yang lain. Jalan keluar desa adatpun dibedakan dengan jalan untuk warga lainnya. Kondisi seperti ini dapat juga diartikan sebagai hukuman bagi yang melakukan poligami, meskipun poligami tidak dilarang asal dilakukan di luar desa adat. Sejak dahulu sampai sekarang hanya satu orang yang berdomisili di karang memadu. Saat ini yang bersangkutan sudah tidak tinggal di kawasan karang memadu karena pindah ke daerah lain. Pindah ke daerah lain berarti tidak terikat lagi dengan ketentuan desa adat.

\section{Keterlibatan Banjar dan/atau Desa Adat sebagai Pengelola \\ Dengan potensi seperti itu, Desa} Penglipuran mulai dikunjungi oleh wisatawan. Namun kunjungan tersebut bukan karena ada potensi seperti itu, tetapi semata-mata disebabkan oleh nama besar Bali. Seiring dengan perkembangan kunjungan wisatawan, berarti dapat juga meningkatkan kesejahteraan masyarakat maupun peningkatan Pendapatan Asli Daerah (PAD). Melihat potensi seperti itu, sangat memungkinkan desa adat penglipuran mampu untuk dijadikan sebagai desa wisata. Pemerintah daerah telah menetapkan desa adat ini sebagai destinasi periwisata Kabupaten Bangli yang dituangkan dalam Peraturan Daerah Nomor 115 Tahun 1993. Sejak saat itu desa wisata ini mulai dikunjungi oleh para wisatawan domestik maupun mancanegara, meskipun belum dikelola secara baik.

Dari tahun ke tahun, dengan semakin banyaknya kunjungan wisatawan ke desa wisata ini, maka beban juru desa semakin berat. Menangani permasalahan adat yang begitu kompleks saja mereka sudah kewalahan, ditambah dengan pengawasan terhadap banyaknya kunjungan wisatawan, maka tanggung jawabnya semakin besar. Dorongan untuk membentuk wadah pengelola kunjungan wisatawan semakin besar, sampai pada akhirnya para tetua adat berjumlah 76 orang yang disebut dengan pengarep (pengambil kebijakan dalam adat) menyetujui pembentukan badan pengelola desa wisata ini. Nama yang disetujui adalah "Badan Pengelola Desa Wisata Penglipuran" ditetapkan pada tanggal 01 Mei 2012 dengan anggota pengelola sebanyak 23 orang dan bertanggung jawab langsung kepada Desa Adat. Menurut (Sudana, 2014:17) Badan pengelola ini mempunyai kedudukan sejajar dengan lembaga adat lainnya seperti: Sekaa Baris, Sekaa Gong, Sekaa Peratengan, Sekaa Pecalang dan Sekaa Teruna dan Lembaga Perkreditan Desa (LPD).

Badan Pengelola Desa Wisata Penglipuran melakukan pembenahan baik teknis operasional pelayanan wisatawan maupun tentang hak dan kewajiban warga desa dalam menikmati hasil pariwisata, yaitu: 
a. Wisatawan yang memasuki desa wisata hanya membayar tiket masuk dan tiket parkir kendaraan. Di koridor jalan menuju puncak jalan, masing-masing rumah dilarang menjual minuman atau makanan. Ini dimaksudkan untuk kebersamaan dan kebersihan lingkungan. Oleh karena itu pengelola menyiapkan kantin yang menampung berbagai macam minuman dan makanan sebagai sumber pendapatan desa wisata. Saat ini harga tiket masuk kawasan desa wisata untuk wisatawan domestik dewasa $\mathrm{Rp}$ 7.500 dan anak-anak Rp 5.000; sedangkan untuk wisatawan asing dewasa Rp 10.000 dan anak-anak Rp 7.500.-. Saat ini wisatawan yang berkunjung ke desa wisata ini pada hari kerja sekitar 200 orang (Domestik $70 \%$ dan Asing 30 $\%)$; sedangkan pada hari libur dan hari besar lainnya, wisatawan yang berkunjung sekitar 500 orang. Kunjungan ini tidak termasuk kunjungan yang berbentuk paket yaitu berkunjung ke beberapa destinasi lokasi pariwisata.

b. Menetapkan rate harga bermalam di home stay serta menetapkan kualifikasi tipe standar baku untuk setiap kelasnya. Untuk tipe berbentuk guest house ( $\mathrm{Rp}$ 500.000/per malam); sedangkan yang berbentuk homestay tipe A (Rp. 300.00/per malam), tipe B (Rp 250.000/per malam), tipe C dan D (Rp. 100.000/per malam)

c. Menyusun prosentasi penggunaan dana yang masuk. Bahkan oleh Ketua Badan Pengelola penyatakan bahwa penyusunannya sudah dilandasi dengan peraturan daerah yaitu $40 \%$ untuk operasional pengelola dan desa adat, sedangkan $60 \%$ untuk Pemerintah Daerah Kabupaten Bangli. Dari $40 \%$ yang diterima oleh badan pengelola $20 \%$ nya untuk desa adat dan 20\% sisanya untuk petugas operasional. Pembagian prosentasi inilah yang digunakan oleh badan pengelola untuk membayar karyawan yang bekerja langsung di desa wisata, juga untuk membiayai setiap upacara keagamaan di desa wisata. Masyarakat secara ekonomis merasakan bahwa desa wisata telah memberikan bantuan untuk melaksanakan upacara keagamaan, namun dari sisi ekonomi pribadi masyarakat belum sepenuhnya terstimuli dari adanya desa wisata.

d. Mendorong pengusaha home industry untuk mengemas produknya secara lebih baik, yaitu produksi khas Desa Wisata Penglipuran berupa anyaman bambu dan minuman loloh-cemcem (minuman dalam kemasan botol dari daun pohon Loloh). Khusus minuman loloh cemcem ini sudah mulai dipasarkan juga di luar wilayah Penglipuran, daerah destinasi pariwisata lainnya dengan bekerjasama dengan pengelola setempat, toko-toko souvenir, maupun warungwarung makanan lainnya. Artinya para pengusaha home industry ini memperoleh manfaat tidak langsung dengan adanya desa wisata ini.

e. Keunggulan potensi Desa Wisata Penglipuran bukan merupakan satu-satunya daya tarik untuk dikunjungi wisatawan. Ketujuh keunggulan potensi yang dimiliki desa wisata ini, memang sudah merupakan fondasi paling penting dalam industri pariwisata, untuk dilihat dan dinikmati. Namun masih ada siklus lain untuk lebih mengikat wisatawan setelah tiba di lokasi desa wisata, yaitu apa yang dibeli, apa yang dilakukan, dan apa yang dipelajari dari Desa Wisata Penglipuran. Siklus ini disebut sebagai "4 in 1" komponen aktivitas di desa wisata. Sudana (2014:31) menyebutnya dengan komponen-komponen kemasan paket wisata yaitu something to see, something to do, something to buy and something to learn.

f. Wisatawan yang sudah datang di Desa Wisata Penglipuran untuk mengetahui dan melihat ketujuh potensi yang ada, kemudian didorong untuk melakukan kegiatan yang sudah dirancang oleh Badan Pengelola Desa Wisata Penglipuran yaitu berkeliling desa (Penglipuran Village Tracking Tour) atau bersepeda mengelilingi perkampungan yang indah (Penglipuran Rural Cycling Tour). Oleh karena itu, keteguhan pengelola melalui banjar atau adat tetap mempertahankan kondisi alam yang asli, tanpa disentuh oleh bangunan ataupun tempat usaha yang berstruktur modern, perlu diberikan apresiasi. Demikian halnya dengan pelestarian nilai budaya yang terkandung dari disediakannya areal khusus yaitu Karang Memadu, maupun bangunan rumah yang seragam bentuk dan bahannya. Setelah aktivitas di lingkungan desa wisata selesai dilakukan, sebelum wisatawan meninggalkan lokasi didorong untuk membeli cindera mata khas Desa Wisata Penglipuran berupa berbagai souvenir kerajinan dari bambu maupun membeli minuman khas Desa Wisata Penglipuran loloh cemcem. Dari ketiga aktivitas tersebut, akhirnya wisatawan memperoleh pelajaran dari berbagai kekhasan budaya desa wisata Penglipuran sebagai siklus aktivitas keempat. Mereka diharapkan dapat memaknai arti budaya subak, filosofi karang memadu, maupun keseragaman bahan dan bangunan rumah.

Mengacu pada paparan konseptual dalam penelitian tahun sebelumnya (tahun 2013) dinyatakan bahwa elemen utama dalam pemberdayaan (Tahajuddin, 2013:50) adalah adanya pembelajaran dan penciptaan sebagai proses sosial yang pada gilirannya menjadi stimulan bagi partisipan untuk mengeluarkan dan meningkatkan segala potensi dan kualitas yang dimilikinya dalam rangka menciptakan kemandirian. Artinya partisipasi merupakan kunci 
untuk mewujudkan kemandirian dan kemampuan dalam mengambil keputusan serta kesiapan menanggung resiko. Dalam hal ini partisipasi yang dilakukan bersifat sukarela sehingga mengarah kepada tindakan yang rasional. Partisipasi mengasumsikan bahwa masyarakat adalah pihak paling mengetahui masalah dan cara pemecahan masalah sesuai dengan rasionalitas mereka. Dengan pendekatan tersebut, keputusan-keputusan yang diambil langsung akan menyentuh kepentingan yang mendesak untuk mereka tangani.

Oleh karena itu Pengelola Desa Wisata Penglipuran telah memberikan stimulan kepada masyarakat untuk ikut bersama-sama dalam mengembangkan dan menjaga desanya sebagai desa wisata. Masyarakat yang kehidupan ekonominya lebih baik, tidak nampak memamerkan kelebihan ekonominya dengan mengikuti perintah pengelola dalam membangun bentuk rumah dan menggunakan bahan yang sama dengan bangunan rumah yang lain. Meskipun dalam kenyataannya, bangunan didalam rumah maupun ornamennya sangat jauh berbeda dengan yang lain. Begitu juga ketentuan-ketentuan desa adat sebagai desa wisata yang menjadi potensi daya tarik wisatawan seperti Karang Memadu tetap dipelihara dan dipatuhi oleh warganya. Hutan bambu yang menjadi milik orang per orang, tidak dapat dijual kepada orang lain dari luar desa wisata, serta tidak boleh diubah menjadi bangunan lain, juga ditaati oleh warganya.

Hal tersebut semata-mata karena pengelola Dewa Wisata Penglipuran melibatkan desa adat dan banjar-banjar yang ada, sehingga aktivitas masyarakat tidak keluar dari adat dan kebudayaan yang ada. Di samping itu, hasil pemasukan dari desa wisata sudah dirasakan oleh masyarakat, misalnya membangun tempat pertemuan banjar dibiayai sepenuhnya oleh pengelola desa wisata, upacara keagamaan di pura juga dibiayai sepenuhnya oleh pengelola. Terlebih lagi para pengusaha home industry khas desa wisata Penglipuran yang memproduksi minuman loloh cemcem dan kerajinan bambu, akan memperoleh nilai tambah dari penghasilan penjualan yang meningkat. Contoh lain dengan keterlibatan Banjar dalam pengelolaan Wisata Kuliner di Desa Kadonganan Jimbaran Bali dapat sukses dan dapat membiayai kebutuhan Banjar itu sendiri. Model CE pada wisata kuliner yang pengelolaannya melibatkan Banjar dan/atau desa adat di desa Kadonganan, Jimbaran, juga berhasil dengan sangat baik. Omsetnya dalam sebulan bernilai ratusan juta rupiah dan masing-masing Banjar yang mengelola cafe dapat membangun gedung Pertemuan milik Banjar dengan biaya sekitar 1-2 milyar rupiah. Harga makanan dan minuman dari 24 cafe yang dikelola dengan melibatkan Banjar dan/atau Desa Adat tersebut adalah "sama". MejaKursi dan taplak meja bentuknya sama, serta setiap dua cafe memiliki satu group pengamen sekitar 5-7 orang yang tidak boleh mangkir mengamen dan tidak boleh pindah cafe. Para pengamen ini sudah memiliki koperasi hasil mengamen, semuanya berasal dari luar pulau Bali. Pada siang hari para pengamen diberi tugas sebagai petugas kebersihan dan keamanan, oleh pengelola disebut sebagai CCTV nya cafe-cafe tersebut. Kawasan wisata kuliner di Desa Kadonganan mempekerjakan 1.100 orang (di luar suplier) ini terletak di pinggir pantai Kedonganan, Jimbaran. Wisata Kuliner ini memiliki enam keunggulan yaitu: dekat pantai Kute, dekat juga pantai Sanur, setiap lima menit dapat melihat pesawat yang akan landing dan take off, menu cumi bakar bumbu basah genap, sambel mentah, dan apabila beruntung dapat melihat Penyu bertelur. Untuk menjaga kebersihan dan keindahan pantai, kawasan ini bebas dari segala bentuk iklan, baik umbul-umbul, spanduk, maupun tulisan/gambar pada tempat-tempat tertentu. Model $\mathrm{CE}$ dalam industri pariwisata melalui wisata kuliner ini dicita-citakan sebagai sustainable tourism milik masyarakat, dapat dijadikan rujukan untuk membangun kawasan kuliner di daerah lain. (Hasil penelitian Model CE pada Wisata Kuliner yang dilakukan juga oleh penulis, akan diterbitkan tersendiri setelah kelengkapan data dikumpulkan dan di klarifikasi lebih lanjut).

\section{Model Community Empowerment}

Enam pendekatan yang digunakan dalam analisis Model Community Empowerment $(C E)^{5}$ dalam Industri Pariwisata di Desa Wisata Penglipuran, membuktikan bahwa peranan banjar dan/atau desa adat menjadi sangat sentral dalam upaya meningkatkan keterlibatan masyarakat tempaan dalam kegiatan pariwisata. Sekaligus masyarakat tempaan dapat meningkatkan kesejahteraannya melalui kegiatan pariwisata. Keenam pendekatan yang dimaksud adalah regulasi, kelembagaan, sinerjitas, mobilisasi SDM lokal, fasilitasi dan perubahan mindset, dapat digambarkan pada Gambar 1.

Model CE Desa Penglipuran sudah memiliki semua hal yang dipersyaratkan sebagai Desa Wisata untuk destinasi pariwisata di Bali. Model ini dapat diacu atau dijadikan referensi untuk daerah lain yang akan mengembangkan desa wisata di daerahnya. Meskipun masih perlu penyempurnaan dalam pelaksanaannya, misalnya pemandu wisata desa dari masyarakat setempat, promosi melalui berbagai media massa maupun melalui travel agent, serta pengisian acara pada saat wisatawan menginap di guest house atau

\footnotetext{
${ }^{5}$ Uraian tentang Model Community Empowernment, selanjutnya dapat dibaca pada Buku Hasil Penelitian Pusat Penelitian Kemasyarakatan dan Kebudayaan (P2KK-LIPI) yang diterbitkan pada Tahun 2014 dengan judul Model Community Empowerment Dalam Industri Pariwisata.
} 
homestay yang ada. Saat ini memang belum disediakan pemandu wisata lokal sebagai bagian dari pelayanan desa wisata. Pemandu wisata yang ada adalah pemandu wisata dari travel agent yang membawa rombongan pariwisata dari luar desa Penglipuran.

Demikian halnya dengan promosi desa wisata ini melalui media massa atau travel agent pariwisata perlu direncanakan dan dilakukan untuk lebih mendorong wisatawan mengunjungi desa wisata Penglipuran ini. Paket-paket pariwisata beserta pembelian souvenirnya sebagai oleh-oleh dari Desa Wisata Penglipuran perlu dipikirkan, sehingga nilai tambah pengusaha loloh cemcem dan pengrajin bambu lebih meningkat. Saat ini, para wisatawan hanya dikutip biaya untuk transpotasi dan uang parkir mobil saja; sedangkan pembelian souvenir diserahkan kepada masing-masing wisatawan.
Dalam Ilmu Komunikasi dikenal adanya simbol yang digunakan untuk menyampaikan pesan, sehingga dalam komunikasi bisnis (desiminasi desa wisata) perlu dilakukan melalui berbagai cara. Tanpa dikomunikasikan, simbol desa wisata sebagai daya tarik kunjungan wisatawan, sulit untuk berkembang. Oleh sebab itu, pengelola desa wisata dapat melakukan kerja sama dengan pihak lain seperti Badan Pengelola Wisata (BPW) untuk memasarkan desa wisata ini. Misalnya dengan melakukan paket wisata yang berisi, wisatawan tidak hanya berhenti berwisata di Pantai Kuta, Pantai Sanur dan pantai lainnya yang sudah dikenal dunia; namun diteruskan dengan berwisata ke desa wisata Penglipuran ini. Terlebih lagi, wisatawan ditawarkan juga menginap pada homestay yang sudah ada di desa wisata ini. Biaya wisata dijadikan satu dengan biaya untuk berwisata di pantai-pantai tersebut, sehingga seolah-olah
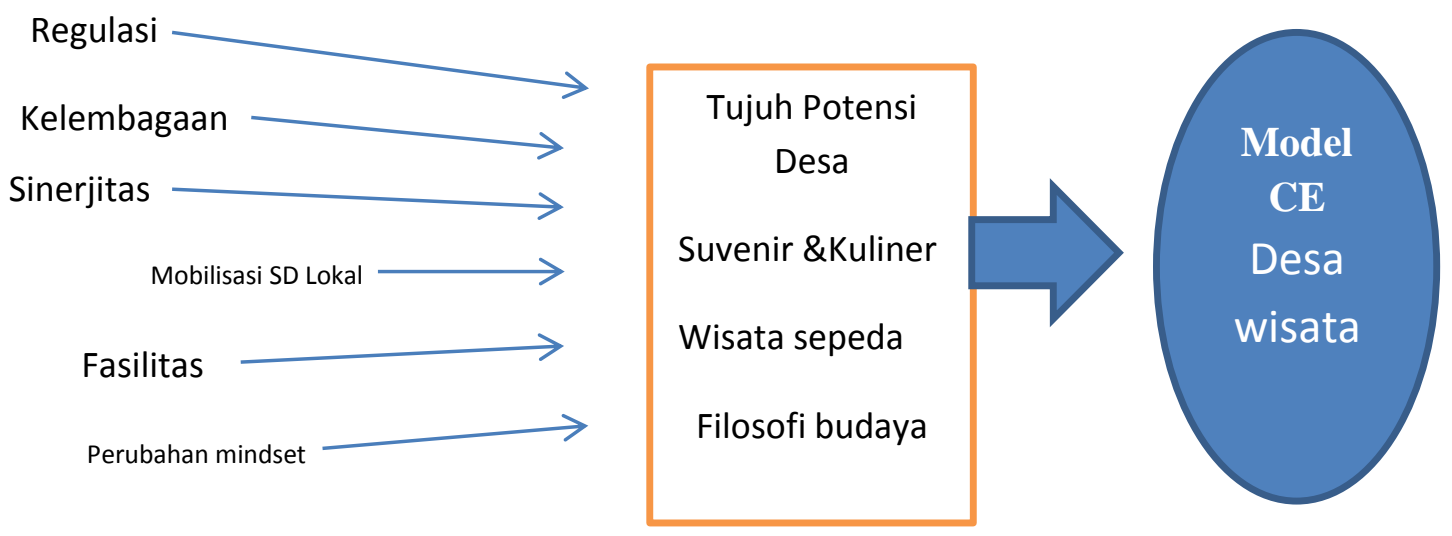

\section{Gambar 1: Model Community Empowerment Desa Wisata (sumber: diolah dari data hasil penelitian)}

Pengisian acara kesenian ataupun pemutaran film budaya desa wisata di malam hari bagi wisatawan perlu dijadikan satu paket dengan biaya lain seperti sewa guest house atau home stay, maupun pembelian souvenirnya. Saat ini, acara malam hari bagi wisatawan yang menginap, hanya dilakukan apabila ada permintaan khusus dari wisatawan yang menginap. Agresivitas dalam marketing dan perencanaan paket paket wisata di desa wisata Penglipuran ini, perlu ditingkatkan. Dengan demikian, maka Desa Wisata Penglipuran ini sudah menjawab definisi desa wisata sebagaimana yang dimaksud oleh Peraturan Menteri Kebudayaan dan Pariwisata (Permenbudpar) Nomor PM.26/UM.001/MKP/2010 yaitu suatu bentuk integrasi antara atraksi, akomodasi, dan fasilitas pendukung yang disajikan dalam suatu struktur kehidupan masyarakat yang menyatu dengan tata cara dan tradisi yang berlaku.

\section{Strategi Komunikasi Pemasaran Desa Wisata Penglipuran}

tidak ada tambahan biaya, walau berwisata di beberapa lokasi. Dengan cara ini, dewa wisata Penglipuran ini akan cepat dikenal dan hasilnya dapat digunakan untuk mensejahterakan masyarakatnya.

Hal-hal seperti inilah yang dianalisis oleh Stephen W Littlejohn (1992) tentang agenda setting dalam buku Theories of Human Communication. Intinya adalah konten media sesungguhnya tidak ditentukan oleh media itu sendiri, melainkan ditentukan juga oleh agenda setting masyarakat. Oleh karena itu, pengelola desa wisata secara kontinyu berinisiatif mencari berbagai bentuk inovasi dan kerjasama dengan berbagai pihak untuk mempromosikan desa wisata. Tidak kalah pentingnya adalah promosi melalui hubungan langsung dengan wisatawan yang sudah pernah datang di desa wisata ini, kemudian dilanjutkan dengan promosi melalui media sosial sebagai akibat dari perkembangan teknologi informasi dan komunikasi (TIK). Penggunaan TIK ini oleh (Imron, 2015) dinyatakan bahwaTIK memainkan peranan penting dalam tatanan sosial dan budaya 
baru membawa perubahan dari media cetak ke media elektronik. Sekaligus kondisi ini akan membawa perubahan proses distribusi pesan, di mana media baru mentransformasi pengalaman individu dan masyarakat tentang pesan media; sehingga media dapat memperpendek pandangan, pendengaran dan sentuhan melalui ruang dan waktu. Memperpendek jarak di antara individu yang bermukim di satu kota dengan kota lain, bahkan memperpendek jarak di antara bangsabangsa yang berbeda negara.

Tentunya infrastruktur dewa wisata terus dikembangkan dan pengelolaannya dilakukan secara profesional, layaknya sebagai distinasi wisata. Disamping itu, penerbitan brosur, pemasangan poster, pemasangan spanduk, dilakukan di tempat-tempat strategis maupun di tempat keramaian lain yang memungkinkan dilihat oleh wisatawan. Promosi yang sama dengan memasang iklan melalui media massa, juga perlu disiapkan dan dilakukan secara masif. Strategi pemasaran yang demikian, secara terus menerus dilakukan sepanjang waktu akan menghasilkan pemasukan dana sebagai salah satu cara peningkatan Pendapatan Asli Daerah.

\section{KESIMPULAN}

Peningkatan Pendapatan Asli Daerah (PAD) dapat dilakukan dengan cara menggali sumbersumber potensi desa, baik yang berbentuk keindahan alam maupun keunikkan budayanya. Tujuh potensi desa adat Panglipuran terus dikembangkan dan dibenahi sesuai dengan perkembangan jaman untuk tetap menjadi daya tarik kunjungan wisatawan. Pemerintah Daerah Kabupaten Bangli Propinsi Bali sudah menetapkan desa Panglipuran sebagai destinasi wisata. Pengelola dewa wisata yang dikoordinir oleh Banjar tinggal merumuskan strategi pemasaran, antara lain dengan cara memasukkan desa wisata ini secara paket kunjungan wisatawan. Paket kunjungan wisata ini dengan melakukan kerjasama dengan agen-agen travel yang sudah biasa mengatur perjalanan paket wisata. Tentu dengan mempertimbangkan keuntungan kedua belah pihak.

Namun sistem pengelolaan Desa Wisata perlu diperkuat dengan cara meningkatkan partisipasi masyarakat dalam pengembangan Desa Wisata ini. Partisipasi Pemerintah daerah diharapkan difokuskan pada penguatan kemampuan sumberdaya manusia dalam mengelola desa wisata, memperkuat pemahaman masyarakat setempat terhadap potensi budaya yang dimiliki, serta mewujudkan visi dan misi pemerintah Kabupaten Bangli untuk mengembangkan Desa Adat Pengelipuran sebagai Desa Wisata dalam rangka meretas jalan meningkatkan kesejahteraan masyarakat maupun peningkatan Pendapatan Asli
Daerah. Pengembangan desa wisata Penglipuran dapat dijadikan model pengembangan desa di tempat lain untuk menjadi destinasi wisata baru, sekaligus untuk meningkatkan pendapatan asli daerah.

\section{Daftar Pustaka}

Archer, B. and Cooper, C. (2004). The positive and negative impacts of tourism, in Evaristus $\mathrm{M}$. Irandu, The role of tourism in the conservation of cultural heritage in Kenya, Asia Pacific Journal of Tourism Research, 9(2), June; Burns \& Holden (1995). Tourism: A New Perspective. Prentice Hall, UK. Dalam Ujud Tahajuddin, dkk 2013, 2014.

Imron, M. Bashori (2015). Pergeseran Media Lama ke Media Baru: Adopsi Ponsel Pintar dan Implikasinya. Dalam Aulia, dkk Media Baru dan Perubahan Masyarakat di Indonesia Pasca Orde Baru: Studi Kasus Adopsi dan Pola Penggunaan Telepon Pintar. Seminar Hasil Penelitian P2KK-LIPI tanggal 10-13 November 2015, di Jakarta

Littlejohn, Stephen W. 1992. Theories of Human Communication Fourth Edition. Belmont California: Wadsworth Publishing Company, A Devision of Wadworth Inc.

Moneng, I Nengah, 2014. Wawancara dengan Ketua Badan Pengelola Desa Wisata Penglipuran. Tanggal 13 Agustus 2014

Peraturan Menteri Kebudayaan dan Pariwisata (Permenbudpar) Nomor PM.26/UM.001/MKP/2010 tentang Desa Wisata

Pitana, I Gede, 1999. Pelangi Pariwisata Bali: Kajian Aspek Sosial Budaya Kepariwisataan Bali di Penghujung Abad. Denpasar, Penerbit Bali Post.

Putra, I Nyoman Darma dan I Gde Pitana. 2010. Pariwisata Pro Rakyat : Meretas Jalan mengentaskan Kemiskinan di Indonesia. Jakarta, Kementerian Kebudayaan dan Pariwisata RI

Sudana, I Putu, dkk. 2014). Laporan Pendahuluan Iptek bagi Masyarakat Kelompok Pengelola Desa Wisata dan Kelompok Karang Taruna. Denpasar, Universitas Udayana.

Tahajuddin, Ujud dkk. 2013. Community Empowerment dalam Industri Pariwisata: Praktik Pemberdayaan Komunitas Lokal oleh Industri Kreatif Pendukung Pariwisata. Jakarta, PT Gading Inti Prima.

Undang Undang Kepariwisataan Nomor 10 Tahun 2009 